\title{
PENGARUH PENAMBAHAN PROBIOTIK DAN MINYAK IKAN PADA PAKAN TERHADAP HISTOPATOLOGI LAMBUNG IKAN SIDAT (Anguilla sp.)
}

\author{
Nailul Izzah $^{\text {a,*, Sulastri Arsad }}{ }^{\text {b }}$, Arning Wilujeng Ekawati ${ }^{\text {a }}$ \\ ${ }^{a)}$ Program Studi Budidaya Perairan, Fakultas Perikanan dan Ilmu Kelautan

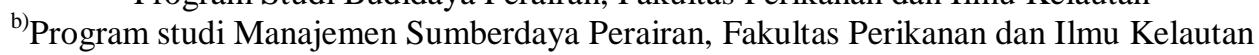 \\ Universitas Brawijaya J1. Veteran Malang 65145, Indonesia \\ *Koresponden penulis : naita89@ub.ac.id
}

\begin{abstract}
Abstrak
Ikan sidat (Anguilla sp.) merupakan jenis ikan yang mempunyai nilai permintaan ekspor yang tinggi di Indonesia. Tetapi pada tahun 2011 volume ekspor menurun sebesar $39.1 \%$ yang diakibatkan oleh lambatnya laju pertumbuhan karena rendahnya daya cerna protein, karbohidrat dan lemak dalam pakan oleh sidat. Oleh karena itu, penambahan probiotik dan minyak ikan pada pakan dapat membantu meningkatkan pertumbuhan ikan selama proses pemeliharaan yang diharapkan dapat meningkatkan profit budidaya. Pemeriksaan histopatologi merupakan salah satu cara dalam mendiagnosis adanya perubahan sel dalam jaringan ikan. Tujuan dari penelitian ini untuk mengetahui tingkat kerusakan histopatologi lambung ikan sidat pasca pemberian probiotik dan penambahan minyak ikan pada pakan. Metode yang digunakan yaitu eksperimental dengan dosis probiotik yang berbeda $10 \mathrm{ml} / \mathrm{kg} ; 15$ $\mathrm{ml} / \mathrm{kg} ; 20 \mathrm{ml} / \mathrm{kg}$ dan $25 \mathrm{ml} / \mathrm{kg}$ dan penambahan minyak ikan masing-masing 5\%. Dari hasil penelitian, nilai skoring kerusakan histopatologi lambung terendah pada perlakuan dosis $15 \mathrm{ml} / \mathrm{kg}$ diperoleh rata-rata dan standar deviasi

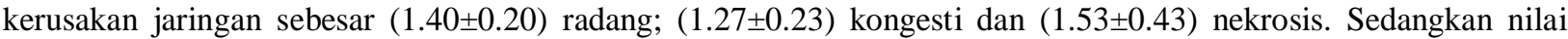
makrofag tertinggi pada dosis $15 \mathrm{ml} / \mathrm{kg}$ dengan nilai $2.13 \pm 0.31$ sehingga dapat disimpulkan bahwa nilai tersebut mampu memberikan perbedaan yang signifikan terhadap histopatologi lambung pada ikan sidat (Anguilla sp.) selama masa pemeliharaan. Penggunaan probitoik dapat menurunkan risiko kerusakan histopatologi lambung ikan sidat dan dapat lebih efektif meningkatkan daya cerna ikan sidat sehingga dapat diaplikasikan pada budidaya ikan sidat (Anguilla sp.) dengan dosis $15 \mathrm{ml} / \mathrm{kg}$ dan minyak ikan 5\% pada pellet guna meminimalisir kerusakan jaringan pada sel.
\end{abstract}

Kata kunci: Histopatologi, Ikan sidat, Kesehatan ikan, Probiotik

\begin{abstract}
Eel fish (Anguilla sp.) demand in Indonesia is high, especially for exporting purpose. However, the export number decreased about $39.1 \%$ in 2011 due to the slow growth rate. This was because the lack of proteins, carbohydrates and fats in eel's feed. Therefore, an addition of probiotic and fish oil on feed could boost the growth of the fish during the rearing process then could increase the aquaculture's profit. Histopathological examination is one way to diagnose the cell changes on fish tissues. The aim of this research was to know the histopathological damage level of eel gastric after probiotic and fish oil addition on feed. Experimental method was carried out during the research with different probiotic doses, consisted of $10 \mathrm{ml} / \mathrm{kg} ; 15 \mathrm{ml} / \mathrm{kg} ; 20 \mathrm{ml} / \mathrm{kg}$ and $25 \mathrm{ml} / \mathrm{kg}$, while fish oil addition was 5\% in each. The results show that the lowest score of gastric histopathological damage found in dose of $15 \mathrm{ml} / \mathrm{kg}$ with average and the standard deviation of inflammation is $1.40 \pm 0.20$; congestion is $1.27 \pm 0.23$; and necrosis is $1.53 \pm 0.43$. Moreover, the highest macrophage value detects at dose of $15 \mathrm{ml} / \mathrm{kg}$ with value $2.13 \pm 0.31$. Based on the results, it can be concluded that the value is able to provide the significant difference in eel's gastric histopathology during the rearing period. The use of probiotic can reduce the risk of histopathological damage in eel's gastric and can effectively increase the digestibility of eel. Thus, an addition of probiotic with dose $15 \mathrm{ml} / \mathrm{kg}$ and $5 \%$ fish oil on feed could be recommended to minimize the tissue damage in cells.
\end{abstract}

Keywords: Fish eel, Fish health, Histopathology, Probiotic

\section{PENDAHULUAN}

Permasalahan utama pada budidaya ikan sidat (Anguilla sp.) adalah pertumbuhan lambat dan konversi pakan yang tinggi. Waktu yang dibutuhkan ikan sidat ukuran 10-20 g untuk mencapai ukuran konsumsi 120 gram adalah 8-9 bulan [1]. Salah satu upaya untuk meningkatkan produksi ikan sidat yang dibudidayakan adalah dengan mempercepat pertumbuhannya melalui pemberian pakan buatan. Indonesia belum memproduksi pakan buatan khusus untuk ikan 
sidat. Oleh karena itu, banyak pembudidaya ikan sidat di Indonesia menggunakan alternatif pakan yang mengandung kadar protein tinggi yang diperuntukkan bagi ikan lain, seperti pakan ikan kerapu, ikan kakap, serta pakan udang.

Pemeriksaan secara histopatologi merupakan pendukung dari suatu diagnosa dan dapat menjadi pemeriksaan diagnosa utama dari suatu penyakit dengan ditemukannya perubahan sel atau jaringan yang spesifik pada penyakit tertentu [2]. Pada saat yang bersamaan, pemeriksaan histopatologi merupakan pemeriksaan lanjutan karena perubahan yang terjadi sering diakibatkan karena perubahan lingkungan (air pemeliharaan ikan) yang terjadi secara ekstrem. Sehingga perlu dilakukan pemeriksaan histopatologi lebih lanjut untuk mengetahui gambaran perubahan sel dan jaringan [3].

Penggunaan probiotik sebagai bentuk pengendalian biologis (biological control) karena perannya dalam membatasi atau membunuh hama dan penyakit, juga berperan dalam mengurangi tingkat kerusakan jaringan ikan. Prinsip dasar kerja probiotik adalah pemanfaatan kemampuan mikroba dalam meningkatkan penyerapan pada jaringan saluran pencernaan ikan. Akan lebih efektif apabila probiotik menggunakan jenis mikroorganisme indigenos (asli) yaitu yang diperoleh berasal dari saluran pencernaan dan lingkungan yang sama/mirip dengan hewan inang [4].

Pemberian probiotik dalam pakan berpengaruh dalam saluran pencernaan, sehingga akan sangat membantu proses penyerapan makanan dalam pencernaan ikan [5]. Bakteri probiotik menghasilkan enzim yang mampu mengurai senyawa kompleks menjadi sederhana sehingga siap digunakan ikan. Dalam meningkatkan nutrisi pakan, bakteri yang terdapat dalam probiotik memiliki beberapa enzim untuk pencernaan pakan seperti amylase, protease, lipase dan selulase.

Berdasarkan uraian tersebut, penelitian penambahan probiotik dan minyak ikan dapat dilakukan pada pakan yang dapat membantu meningkatkan pertumbuhan ikan sehingga dapat menguntungkan bagi pembudidaya dalam melakukan proses pemeliharaan sehingga diharapkan dapat meningkatkan profit dan budidaya dapat dilakukan secara berkelanjutan.

\section{METODE PENELITIAN}

Desain penelitian menggunakan Rancangan Acak Lengkap (RAL) dengan 4 perlakuan, 1 kontrol dan 3 kali ulangan pada tiap perlakuan. Ikan sidat yang digunakan berukuran $\pm 20 \mathrm{~cm}$ dan dosis probiotik+minyak ikan yang digunakan yaitu $10,15,20,25 \mathrm{ml} / \mathrm{kg}$ dan penambahan minyak ikan 5\% masing-masing dosis. Penelitian ini dilaksanakan di Laboratorium Budidaya Ikan divisi Penyakit dan Kesehatan Ikan, Fakultas Perikanan dan Ilmu Kelautan dan Balai Karantina Ikan dan Pengendali Mutu (KIPM) Kelas I Surabaya I, pada bulan Agustus sampai dengan Oktober 2018.

\section{Media Tumbuh Kandidat Probiotik selama Fermentasi}

Media tumbuh yaitu air tawar, air kelapa tua dan air dengan salinitas 10 ppt dimasak dengan kompor gas pada suhu $100^{\circ} \mathrm{C}$. Bahanbahan lain yang digunakan meliputi rempahrempah, molase, dedak halus, susu, dan buah nanas juga ditambahkan dalam proses pemasakan.

\section{Isolasi Bakteri}

Isolat bakteri dari media agar diambil dengan menggunakan jarum ose pada ruang steril. Isolat ditanam pada media TSB dalam sebanyak 1 ose, selanjutnya diinkubasi pada suhu $35^{0}$ C. Pertumbuhan sel bakteri diamati setiap jam pada 5 jam pertama yang kemudian setiap 2 jam sekali dengan menggunakan spektrofotometer pada panjang gelombang 600 $\mathrm{nm}$. Apabila telah didapatkan nilai pada setiap jam pengamatan maka didapatkan persamaan untuk menghitung kepadatan isolat bakteri. Kepadatan bakteri yang didapatkan untuk diisolasikan pada media tumbuh sebagai kandidat probiotik yaitu Bacilus s. $10^{9} \mathrm{cfu} / \mathrm{ml}$, Nitrosomonas $10^{8} \mathrm{cfu} / \mathrm{ml}$, dan Nitrobacter $10^{10}$ $\mathrm{cfu} / \mathrm{ml}$.

\section{Pengambilan Organ}

Pengambilan sampel lambung ikan sidat dilakukan pada 48 jam kemudian dilakukan pengamatan histopatologi. Jaringan diperbaiki dengan merendam dalam $2 \mathrm{ml}$ larutan davidson's dan dibiarkan selama 24 jam. Setelah fiksasi, dilanjutkan dengan proses embedding (penyelubungan parafin) dalam konsentrasi multilevel alkohol dan larutan xilol, dan ditanam dalam parafin. Semua proses ini dilakukan dengan prosesor jaringan. Blok-blok yang terbentuk dari proses embedding kemudian dipotong menggunakan mikrotom dengan ketebalan irisan $5 \mu$. Hasil potongan yang tipis 
dan menyerupai pita diletakkan di atas permukaan air di dalam waterbath $\left(40^{\circ} \mathrm{C}\right)$ sampai jaringan mengembang dengan baik. Jaringan kemudian diangkat menggunakan obyek Glass dan dikeringkan menggunakan slide drying bench selama 10 menit. Objek kaca diatur dalam kotak pewarna kemudian dilakukan pewarnaan menggunakan Harri's Hematoksilin dan Eosin. Pengamatan dilakukan menggunakan mikroskop.

\section{Analisis Histopatologi}

Hasil uji histopatologi lambung ikan sidat menggunakan analisis secara deskriptif. Untuk mengetahui tingkat kerusakan jaringan lambung ikan sidat yang telah diberi probiotik dan minyak ikan pada pakan komersial dengan dosis berbeda maka dilakukan analisis statistik pemberian skoring yaitu pemberian skor terhadap masingmasing parameter untuk menentukan tingkat penilaiannya pada jaringan [6] dengan metode semi kuantitatif yaitu metode analisis yang menggunakan angka skala untuk tiap kategori kualitatif [7]. Menurut yang digunakan untuk menghitung jumlah area yang ter warnai dan dilakukan secara manual dengan menghitung persentasenya. Pembacaan dimulai dari tepi kiri (sesuai dengan posisi ekor preparat) ke arah kepala kemudian turun ke bawah dan bergeser ke arah ekor kembali (gerak zig-zag).

Setiap bidang lapang pandang diamati tingkat kerusakan jaringannya dengan kriteria nekrosis (kerusakan sel), nekrosis (kerusakan sel), odem (pembengkakan sel) dan kongesti kemudian dipersentase dengan pemberian skor dari angka 1 sampai 4. Angka 1 mempunyai tingkat persentase kerusakan jaringan $0-5 \%$, angka 2 tingkat persentase kerusakan jaringan 6-25\%, angka 3 tingkat persentase kerusakan jaringan 26-50\% dan angka 4 tingkat persentase kerusakan jaringan $>50 \%$.

\section{HASIL DAN PEMBAHASAN}

Dari hasil yang didapat penambahan probiotik dan minyak ikan tidak memberikan pengaruh negatif (aman) pada hasil histopatologi lambung ikan sidat. Dari beberapa hasil histopatologi terlihat beberapa kapiler darah mengalami Radang, Kongesti, haemoragi dan nantinya kerusakan tersebut akan mengakibatkan kematian sel atau bisa disebut dengan nekrosis. Dari beberapa dosis pemberian probiotik dan minyak ikan yang diberikan yaitu dosis $10 \mathrm{ml} / \mathrm{kg}$ $+5 \%$ minyak ikan, $15 \mathrm{ml} / \mathrm{kg}+5 \%$ minyak ikan, $20 \mathrm{ml} / \mathrm{kg}+5 \%$ minyak ikan dan $25 \mathrm{ml} / \mathrm{kg}+5 \%$ minyak ikan dapat dilihat gambaran histopatogi lambung ikan sidat. Sedangkan perlakuan kontrol yaitu tanpa pemberian probiotik dan tanpa pemberian minyak ikan pada gambar di bawah ini.

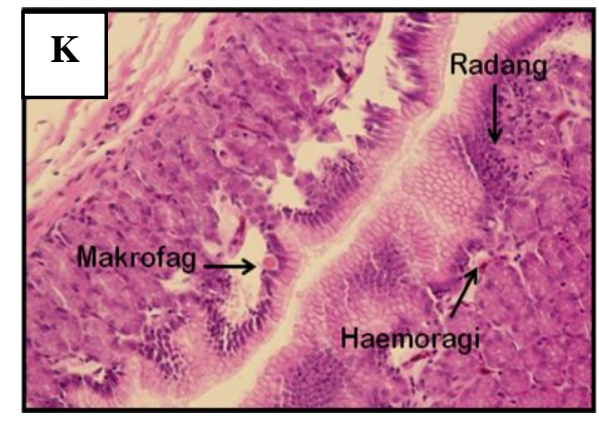

Gambar 1. Gambaran histopatologi lambung ikan sidat kontrol (tanpa pemberian probiotik dan minyak ikan)
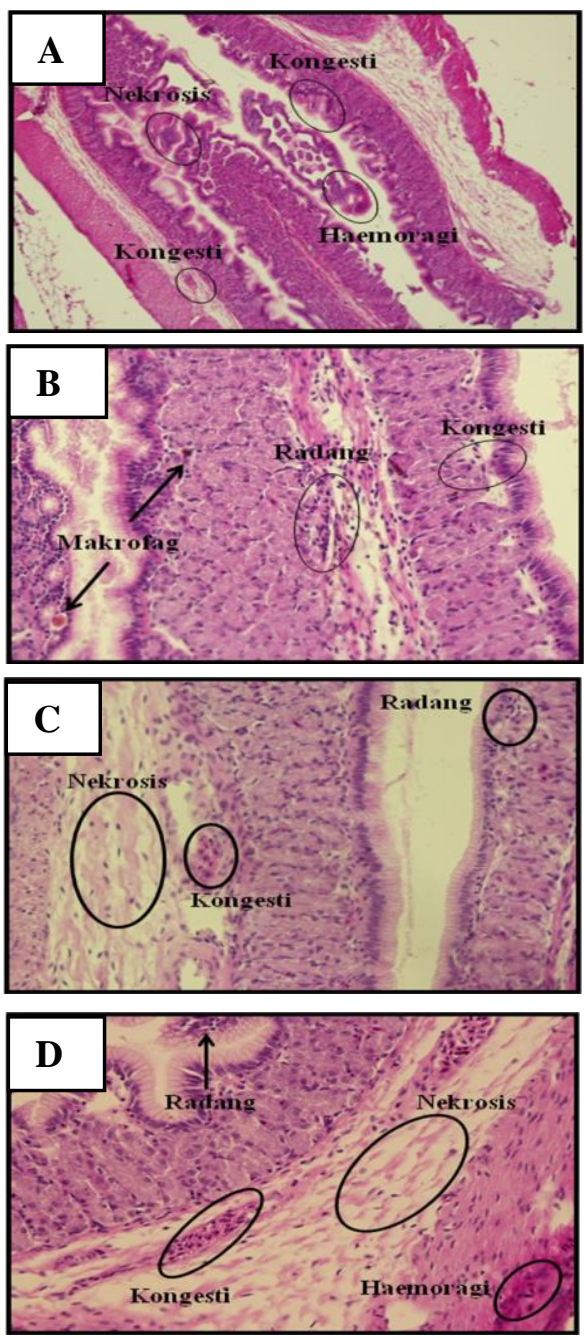

Gambar 2. Gambaran histopatologi lambung ikan sidat. Dosis $10 \mathrm{ml} / \mathrm{kg}+5 \%$ minyak ikan (A); Dosis 15 $\mathrm{ml} / \mathrm{kg}+5 \%$ minyak ikan (B); Dosis $20 \mathrm{ml} / \mathrm{kg}+5 \%$ minyak ikan (C) dan Dosis $25 \mathrm{ml} / \mathrm{kg}+5 \%$ minyak ikan.

Pada gambaran histopatologi lambung tersebut dapat simpulkan bahwa perlakuan yang banyak mengalami banyak jenis kerusakan pada jaringan adalah perlakuan D dengan dosis 25 
$\mathrm{ml} / \mathrm{kg}+5 \%$ minyak ikan dengan rerata radang $(2,13 \pm 0,12)$ nekrosis $(2,13 \pm 0,58)$ dan kongesti $(2,00 \pm 0,35)$, sedangkan perlakuan $\mathrm{B}$ dengan dosis probiotik $15 \mathrm{ml} / \mathrm{kg}+5 \%$ minyak ikan memberikan dampak kerusakan pada gambaran histopatologi lampung terendah dengan nilai rerata radang $(1.40 \pm 0.20)$; kongesti $(1,27 \pm 0,23)$; dan nekrosis $(1,53 \pm 0,43)$. Perlakuan B merupakan dosis optimum dalam ambang batas dosis penambahan probiotk dan minyak ikan yang aman digunakan untuk meningkatkan daya cerna ikan sidat dari segi histopatologi keadaan lambung. Jenis probiotik yang aman digunakan adalah probiotik yang tidak memiliki efek resistensi sehingga aman digunakan dalam jangka waktu panjang [8]. Hal tersebut membuktikan beberapa dosis dapat mempengaruhi tingkat kesehatan ikan. Perbedaan hasil kerusakan jaringan dari hasil histopatologi dapat dilihat pada histogram di bawah ini.

Salah satu manfaat probiotik dalam lingkungan budidaya adalah untuk meningkatkan respons imun pada inang sehingga tahan terhadap infeksi virus, bakteri jamur maupun parasit [9].

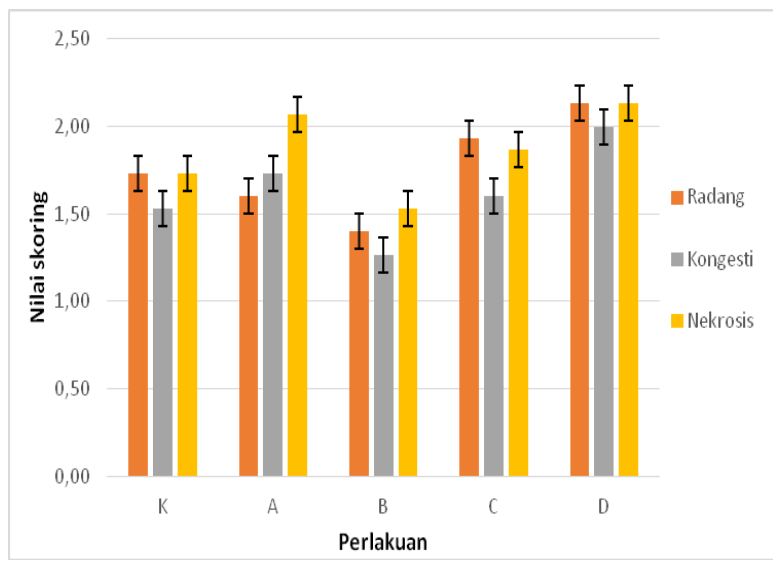

Gambar 3. Histogram nilai skoring histopatologi pada lambung ikan sidat.

Dosis probiotik dengan penambahan minyak ikan yang optimum digunakan dalam penelitian ini dari segi tingkat kerusakan histologi lambung ikan sidat adalah pada perlakuan B $(15 \mathrm{ml} / \mathrm{kg}+5 \%$ minyak ikan $)$. Karena pada perlakuan ini, nilai kerusakan nekrosis, kongesti dan radang/edema memiliki nilai skoring terkecil dari setiap perlakuan, bahkan lebih kecil dari ikan kontrol tanpa perlakuan. Hal tersebut membuktikan bahwa penambahan probiotik dan minyak ikan dengan dosis $15 \mathrm{ml} / \mathrm{kg}+5 \%$ dapat menurunkan risiko kerusakan histologi lambung ikan sidat dan dapat lebih efektif meningkatkan daya cerna ikan sidat.

Hasil skoring makrofag yang berbanding terbalik terhadap hasil histologi lambung ikan sidat. Pada perlakuan B memberikan hasil rerata skoring tertinggi sebesar $2,13 \pm 0,21$ dan hasil tersebut jauh berbeda dengan ikan kontrol tanpa perlakuan yang memiliki nilai rerata sebesar 1,07 $\pm 0,12$. Peningkatan jumlah makrofag setelah pemberian probiotik menunjukkan adanya stimulasi imun non spesifik terhadap sel makrofag dikarenakan terjadi proses proliferasi dan diferensiasi dari sel-sel hasil stimulasi oleh adanya probiotik yang berfungsi sebagai imunostimulan. Sedangkan pada perlakuan C $(1,40 \pm 0,20)$ dan $\mathrm{D} \quad(1,70 \pm 0,12)$ mengalami penurunan rerata jumlah makrofag seiring bertambahnya dosis probiotik dan minyak ikan yang diberikan hal ini dikarenakan kombinasi komposisi probiotik dan minyak ikan yang digunakan pada dosis $\mathrm{C}$ dan $\mathrm{D}$ sudah bersifat imunosupresif, yaitu dapat menekan kerja imun. Perbedaan hasil jumlah makrofag dari hasil histopatologi dapat dilihat pada histogram di bawah ini.

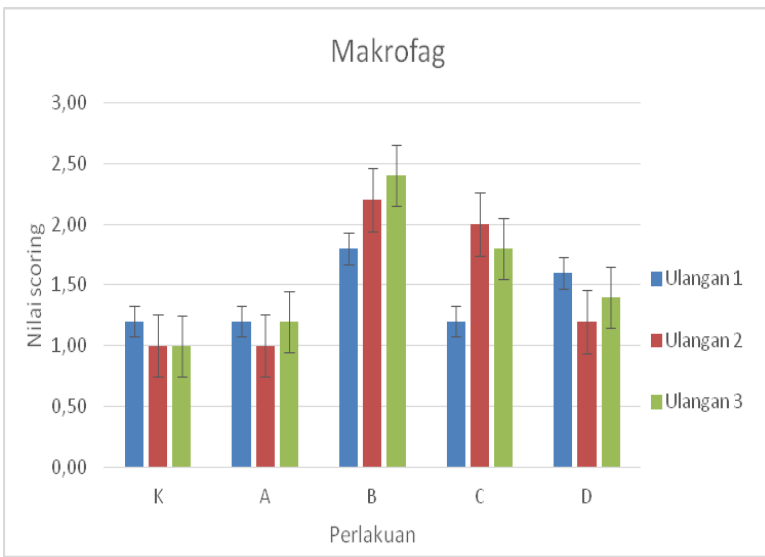

Gambar 4. Histogram nilai skoring jumlah makrofag pada lambung ikan sidat

\section{KESIMPULAN}

Berdasarkan hasil penelitian dapat disimpulkan bahwa penambahan probiotik dengan minyak ikan mampu memberikan perbedaan yang signifikan terhadap histopatologi lambung ikan sidat selama masa pemeliharaan. Hasil perlakuan terbaik pada penelitian ini adalah perlakuan B (probiotik $15 \mathrm{ml} / \mathrm{kg}$ dengan minyak ikan $5 \% / \mathrm{kg}$ pakan) kerusakan histopatologi lampung terendah dengan nilai rerata radang (1.40 \pm 0.20$)$; kongesti $(1,27 \pm 0,23)$; dan nekrosis $(1,53 \pm 0,43)$. Sedangkan untuk hasil skoring makrofag yang berbanding terbalik terhadap hasil histologi lambung ikan sidat. Pada perlakuan B memberikan hasil rerata skoring tertinggi sebesar $2,13 \pm 0,21$. 


\section{UCAPAN TERIMA KASIH}

BPP FPIK-UB yang telah memberikan dana dalam pelaksanaan penelitian ini. Balai Karantina Ikan dan Pengendali Mutu (KIPM) Kelas I Surabaya I yang telah membantu dalam proses analisa histopatologi.

\section{DAFTAR PUSTAKA}

[1] Yudiarto S, Arief M, Agustono. "Pengaruh penambahan atraktan yang berbeda dalam pakan pasta terhadap retensi protein, lemak dan energi benih ikan sidat (Anguilla bicolor) stadia elver". JIPK. 4(2): 135-140, 2012.

[2] Setyowati, A., D. Hidayati., Awik P. N. dan N. Abdulgani. "Studi histopatologi hati Ikan Belanak (Mugil cephalus) Di Muara Sungai Aloo Sidoarjo". Jurnal Akuakultur. 1(1): 110, 2010.

[3] Arief, M., N. Fitriani dan S. Subekti. "Pengaruh pemberian probiotik pada pakan komersial terhadap pertumbuhan dan efisiensi pakan ikan lele sangkuriang (Clarias sp.)". Jurnal ilmiah perikanan dan kelautan. 6(1): 49-53, 2014.

[4] Yulvizar, C., I. Dewiyanti dan C. N. Defira. "Seleksi bakteri berpotensi probiotik dari ikan mas (cyprinus carpio) indegenous jantho berdasarkan aktivitas antibakteri secara in vitro". Jurnal Teknologi dan Industri Pertnian Indonesia. 6(2): 44-48, 2014.

[5] Feliatra, I. Efendi, dan E. Suryadi. "Isolasi dan Identifikasi Bakteri probiotik dari ikan kerapu macan (Ephinephelus fuscoguttatus) dalam upaya efisiensi pakan ikan". Jurnal Natur Indonesia. 6(2): 75-80. 2004.

[6] Gaspersz, V. "Teknik analisis dalam penelitian percobaan". Tarsito, Bandung, 1991.

[7] Kakkilaya, B. S. "Periphelar smear Examination For Malaria Parasite”. Dr. B. S. Kakkilaya's Malaria Wed site, 2002.

[8] Andayani, Sri., Suprastyani, Heny., Galih. D. A. G.., Uswanul O., Nela M. F., Maulana W., Anisatul F., dan Randi P. "Pengaruh Pemberian Bakteri Lactobacillus plantarum Terhadap Histopatologi dan Hematologi Ikan Patin Jambal (Pangasius djambal) yang Diinfeksi Bakteri Edwarsiella tarda". Journal of Fisheries and Marine Science. 1(4): 31-38, 2017.

[9] Kurniasih, Titin., Marina L. A., Zafril I. A., dan Irma M.. "Isolasi Dan Seleksi Bakteri Saluran Pencernaan Ikan Lele Sebagai Upaya Mendapatkan Kandidat Probiotik Untuk Efisiensi Pakan Ikan". J. Ris. Akuakultur. 9(1): 99-109, 2014. 